\begin{tabular}{|c|c|c|}
\hline institute & $\begin{array}{l}\text { CARADDE: Jurnal Pengabdian Kepada Masyarakat } \\
\text { https://journal.ilininstitute.com/index.php/caradde } \\
\text { Volume } 2 \text { | Nomor 1 | Agustus | 2019 } \\
\text { e-ISSN: } 2621-7910 \text { dan p-ISSN: } 2621-7961 \\
\text { DOI: https://doi.org/10.31960/caradde.v2i1.264 }\end{array}$ & $\begin{array}{l}\text { Itîn } \\
\text { garadoE }\end{array}$ \\
\hline
\end{tabular}

\title{
Peningkatan Kualitas Produksi melalui Transformasi Kemasan Produk Pada Usaha Pembuatan Jamu Kunyit
}

\author{
Muhammad Assidiq ${ }^{1}$, Basri $^{2}$
}

\begin{tabular}{ll}
\hline \hline Keywords: & Abstrak. Potensi Desa Kunyi sebagai daerah yang ditumbuhi \\
UMKM; & tanaman Kunyit (Curcuma longa Linn. syn. Curcuma \\
Desa Kunyi; & domestica Val.) yang melimpah justru menjadi permasalahan \\
Jamu; & bagi petani perkebunan. Di sebagian besar di daerah \\
Kunyit; & pegunungan yang dominan di desa Kunyi, hampir semua \\
Transformasi Produk; & ditumbuhi dengan umbi Kunyit, bahkan menurut hasil \\
& wawancara dan observasi, Umbi Kunyit ini justru menjadi \\
Corespondensi Author & pengganggu di lahan perkebunan. Kegiatan pengabdian yang \\
Program Studi Teknik Informatika, & dilakukan bertujuan untuk membina kelompok KWT Melati \\
Universitas Al Asyariah Mandar, & mengolah bahan Kunyit menjadi Jamu Kunyit dengan \\
Sulawesi Barat, Indonesia. & kemasan dan manajemen usaha yang standar. Permasalahan \\
Email: basri@unasman.ac.id. & kegiatan usaha yang ditemukan adalah bentuk produk dalam \\
& bentuk cair dan hanya bertahan satu pekan. Untuk itu \\
History Artikel & melalui Program Kemitraan Masyarakat (PKM), tahapan \\
Received: Juli-2019; & awal yang dilakukan berupa kegiatan pendampingan desain \\
Reviewed: Juli -2019 & dan pembuatan kemasan dan label produk yang awalnya \\
Accepted: Agustus-2019 & berupa cair dan dikemas pada botol bekas menjadi kemasan \\
Published: Agustus-2019 & yang lebih modern dan menarik. Selain itu manajemen usaha \\
& melalui pendekatan pendampingan perencanaan bisnis juga \\
& dilakukan. Hasil kegiatan pendampingan program yang \\
& dilakukan didapatkan hasil konversi produk cair menjadi \\
& bubuk dan dikemas menggunanakan kemasan produk dengan \\
kemasan dan label yang lebih menarik dan tahan lama. & Selain itu hasil kegiatan didapatkan dokumen perencanaan \\
\hline \hline
\end{tabular}

(c) (1) This work is licensed under a Creative Commons Attribution

4.0 International License

\section{PENDAHULUAN}

Desa Kunyi sebagai desa pemekaran dari Kelurahan Anreapi memiliki luas wilayah $15,72 \mathrm{~km}$ dan penduduk 1.712 jiwa dengan jumlah kepala keluarga $384 \mathrm{kk}$ terdiri dari 7 dusun. Desa Kunyi berjarak sekitar 12 $\mathrm{Km}$ dari ibu kota kabupaten Polewali Mandar dan berada di Kecamatan Anreapi. Terletak di wilayah pegunungan dengan kurang lebih $90 \%$ diantaranya menggantungkan hidup dari hasil pertanian di desa tersebut (BPS, 2016).
Berdasarkan data BPS dan observasi lapangan, desa Kunyi yang memiliki hasil alam yang melimpah, diantaranya kelompok tanaman padi-padian, umbi-umbian, jahejahean, kacang-kacangan dan sayuran hingga buah. Dengan hasil alam yang melimpah, membuat ibu-ibu Kelompok Wanita Tani (KWT) Melati di dusun Rarekan memanfaatkan keadaan ini dengan membuat olahan jamu kunyit dari melimpahnya kunyit di desa tersebut. Desa Kunyi sebagaimana asal namanya merupakan daerah yang memiliki potensi alam Tanaman Kunyit 
Caradde: Jurnal Pengabdian Kepada Masyarakat

Vol 2 No 1, Agustus 2019

(Curcuma longa Linn. syn. Curcuma domestica Val.) (Pribadi, 2015).

Di sebagian besar di daerah pegunungan yang dominan di desa Kunyi, hampir semua ditumbuhi dengan umbi Kunyit, bahkan menurut hasil wawancara dan observasi, umbi Kunyit ini justru menjadi pengganggu di lahan perkebunan, karena umbinya dapat merapuhkan struktur tanah perkebunan yang tentunya tidak baik bagi usaha perkebunan seperti Cokelat, Kopi dan tanaman perkebunan lainnya.

Latar belakang kegiatan usaha mitra yang dilakukan sudah baik namun bentuk hasil produksi dalam bentuk cair dan hanya bertahan satu pekan merupakan masalah yang perlu mendapat perhatian. Selain itu usaha produksi jamu kunyit masih dikelola secara tradisional tanpa menajemen usaha dan perencanaan bisnis yang baik. Walaupun dikerjakan secara kekeluargaan dan saling menguntungkan antar anggota kelompok, namun hasil produksi dan pemasaran tidak begitu meluas. Kemasan produk saat ini masih menggunakan kemasan botol bekas sehingga menjadi salah satu faktor kurangnya minat pembeli dan daya jual produk (Bora \& Bayu, 2018).

Untuk itu melalui kegiatan pengabdian kepada masyarakat di desa kunyi pada Kelompok Wanita Tani dilakukan kegiatan pendampingan dengan pendekatan model Edukatif, Model Participatory Rural Appraisal (PRA) (Zakaria, 2018), Model Participatory Technology Development (Mandloi et al., 2014), dan Model Community development (Triyono, 2014).

\section{METODE}

Sebagaimana analisis masalah dalam rangka peningkatan kesejahteraan kelompok UKM KWT Melati dalam melakukan kegiatan, maka rencana tindakan yang diusulkan setelah dilakukan analisis kebutuhan dan permasalahan usaha mitra, maka dibutuhkan pendekatan manajemen usaha yang baik. Selain itu terkait permasalahan kemasan dan label produk diperlukan pelatihan dan pendampingan pembuatan kemasan dan label. Pengemasan produk tentunya akan membawa pengaruh positif terhadap minat konsumen untuk membeli produk (Basri \& Qashlim, 2018).

Kualitas produk sangat bergantung pada khasiat dan pembuktian secara klinis, namun untuk kuantitas tentunya dipengaruhi oleh daya beli pasar terhadap produk tersebut. Kepercayaan terhadap khasiat dan daya tahan produk juga menjadi faktor utama sehingga tantangannya adalah bagaimana melakukan pendampingan terkait diversifikasi dan pengemasan produk yang tahan lama. Produk yang telah dibina setelah memenuhi standar kualitas, maka selanjutnya dapat dipromosi dengan memanfaatkan teknologi pada teknologi e-commerce yang menggabungkan kegiatan distribusi, penjualan, pembelian, marketing dan service dalam satu aplikasi (Wibowo, 2016).

Kegiatan perencanaan solusi melalui penarikan masalah hingga perencanaan luaran sebagaimana disajikan pada tabel 1, dan konsep tahapan kegiatan sebagaimana disajikan pada gambar 1 .

Tabel 1: Perencanaan solusi melalui penarikan masalah mitra

\begin{tabular}{|c|c|c|c|}
\hline No & Bidang & Target Kinerja & Target Luaran \\
\hline \multirow[t]{2}{*}{1} & Manajemen & Bagaimana membuat & Adanya Dokumen Perencanaan \\
\hline & Usaha & perencanaan usaha yang baik. & $\begin{array}{l}\text { Usaha, Pencatatan, dan Model } \\
\text { Pelaporan } \\
\text { Metode: Pendampingan }\end{array}$ \\
\hline \multirow[t]{2}{*}{2} & Kemasan & Bagaimana membuat kemasan & Adanya desain kemasan dan label \\
\hline & $\begin{array}{l}\text { dan Label } \\
\text { Produk }\end{array}$ & dan label yang menarik. & $\begin{array}{l}\text { berbasis desain grafis, } \\
\text { Metode: Implementasi Kepakaran } \\
\text { Desain }\end{array}$ \\
\hline \multirow[t]{2}{*}{3} & Kualitas & Bagaimana & Adanya varian produk dan \\
\hline & produk & $\begin{array}{l}\text { diversifikasi } \\
\text { tahan lama. }\end{array}$ & $\begin{array}{l}\text { perubahan produk dari cair ke } \\
\text { bubuk sehingga tahan lama. } \\
\text { Metode: Pendampingan }\end{array}$ \\
\hline
\end{tabular}




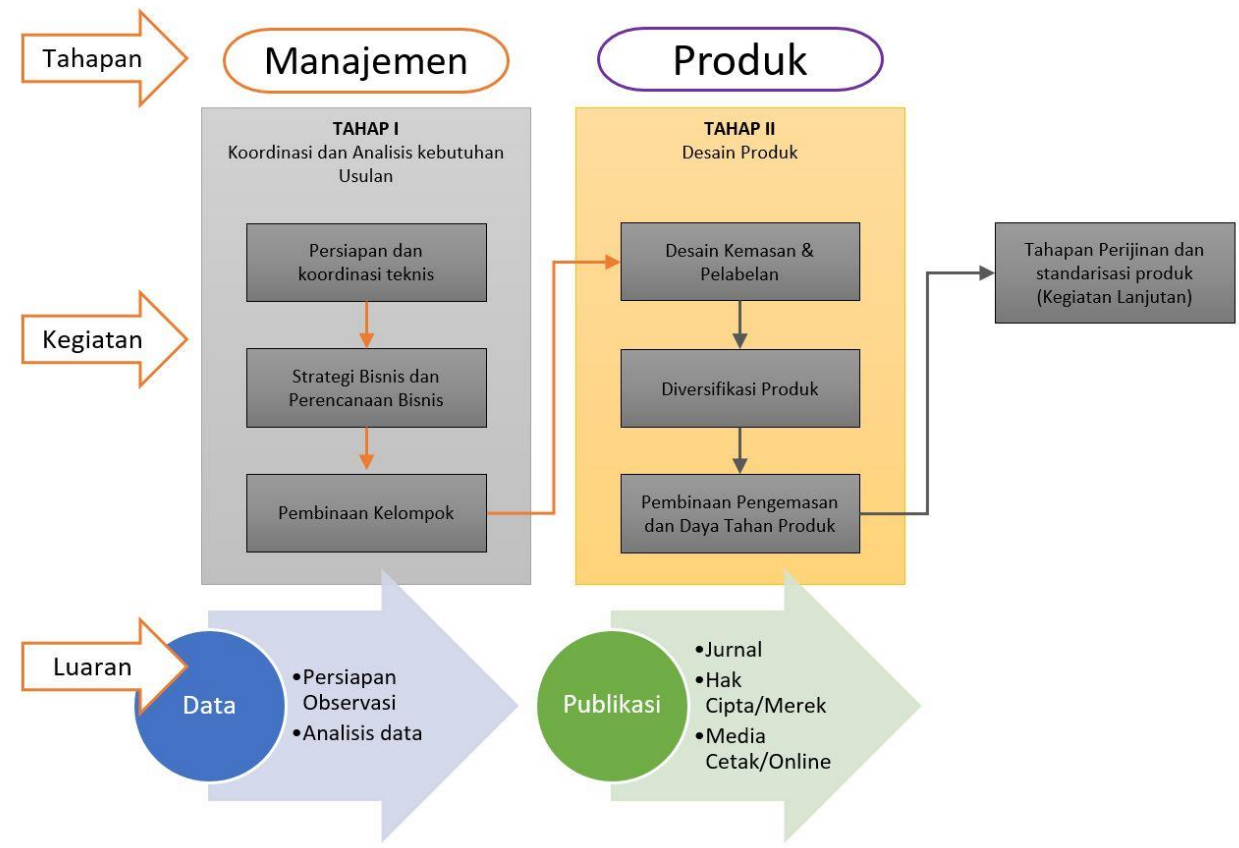

Gambar 1: Tahapan kegiatan

Tahapan pelaksanaan secara garis besar dijelaskan sebagai berikut :

a) Tahap I, berupa Koordinasi dan Analisis kebutuhan Usulan yang terdiri dari :

1. Persiapan dan koordinasi, pada tahapan ini koordinasi lanjutan dilakukan untuk memperkuat implementasi usulan di desa mitra.

2. Strategi Bisnis dan Perencanaan Bisnis, pada tahapan ini dibuat model proses bisnis yang sistematis (Sari, 2019).

3. Pembinaan Kelompok dilakukan menggunakan metode pelatihan partisipatif (Zakaria, 2018).

b) Tahap II, berupa Desain Produk yang terdiri dari :

1. Desain Kemasan dan Pelabelan, pada tahapan ini produk dievaluasi dan dibuatkan model kemasan yang standar serta pemberian merek dan pelabelan produk. Penggunaan merek didasari atas pentingnya penggunaan warna, bentuk, logo, ukuran, bahan dan label karena dapat berpengaruh positif dan signifikan terhadap minat beli konsumen (Hidayah, 2016), (Pramudita, 2013).

2. Diversifikasi Produk, pada tahapan ini kelompok dibina untuk memproduksi produk dengan varian khasiat berdasarkan hasil diskusi dan analisis pasar.
3. Pembinaan Pengemasan dan Daya Tahan Produk, pada tahapan ini kelompok dibina untuk mendesain produk kering dan pengemasannya sehingga daya tahan produk lebih terjamin .

\section{HASIL DAN PEMBAHASAN}

Kegiatan awal di desa kunyi telah dilakukan melalui program pengabdian pendahuluan melalui pembinaan kelompok KWT Mekar, namun dengan kegiatan UKM yang berbeda (Basri \& Qashlim, 2018). Atas dasar ini, hasil observasi awal di desa menunjukkan tingkat masalah yang sama, tentunya dengan penerapan pendampingan yang sama namun dengan pendekatan yang berbeda.

Tingkat partisipasi kelompok pada dasarnya sudah cukup tinggi, sehingga melalui kegiatan pendampingan awal telah adanya peningkatan wawasan terkait pentingnya kemasan dan pelabelan produk yang standar bagi peningkatan kualitas produk usaha. KWT Melati di Desa Kunyi Kecamatan Anreapi Kabupaten Polewali Mandar dengan usaha pembuatan jamu telah digeluti dengan baik namun model kemasan yang berupa botol bekas dan pengemasan dalam bentuk cair akan sulit menyentuh pasar 
Caradde: Jurnal Pengabdian Kepada Masyarakat

Vol 2 No 1, Agustus 2019

yang lebih luas dan modern.

Hasil kegiatan awal setelah dilakukan pendampingan melalui diskusi kelompok bersama mitra disepakati hasil evaluasi kemasan produk, merek, dan label produk. Setelah dilakukan diskusi dan analisa maka dibuatlah merek dagang dengan nama "Marasa Kunyit". Kegiatan awal pertemuan dan pendampingan mitra sebagaimana ditunjukkan pada Gambar berikut.

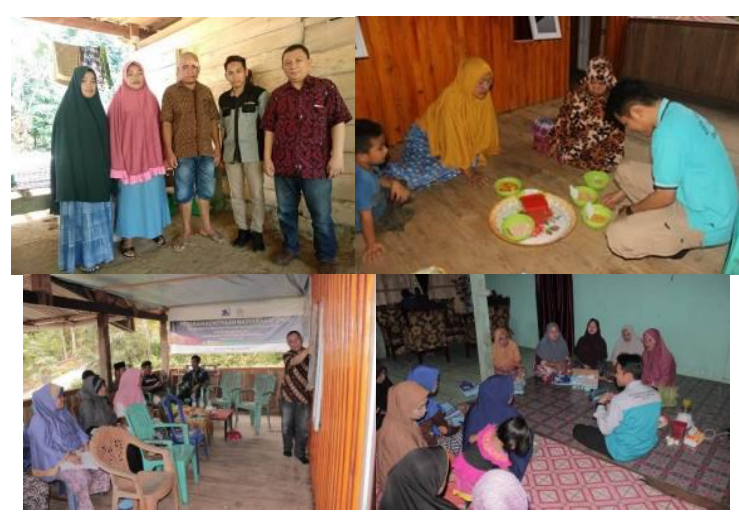

Gambar 2: Koordinasi dan pendampingan awal

Pemberian nama diusulkan bernuansa kedaerahan dengan kata awal "Marasa" yang bersumber dari bahasa daerah Mandar yang berarti "memiliki rasa", atau dapat juga diartikan konotasi sangat baik untuk suatu sajian makanan atau minuman dalam dialeg daerah Mandar. Sedangkan kata "Kunyit" merujuk pada pilihan bahan baku utama jamu kunyit yang dipromosikan dalam produk ini sehingga merek ini disetujui untuk digunakan.

Selanjutnya terkait kemasan, hasil observasi menunjukkan bahwa kemasan yang digunakan awalnya sangat tidak memenuhi standar produk, baik kualitas, kesehatan maupun standar keamanan kemasan. Untuk itu pada kegiatan pendampingan tahap II produk yang awalnya cair kemudian di transformasi menjadi bentuk bubuk. Proses pembuatan produk menjadi bubuk, dengan mendampingi dan mengarahkan mitra agar bahan baku yang semula basah kemudian dikeringkan, kemudian dihaluskan dengan alat penghalus bumbu. Bahan baku produk dari padat menjadi bubuk sebagaimana ditunjukkan pada gambar berikut.

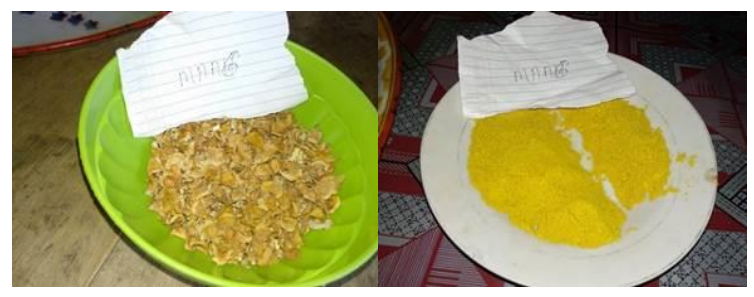

Gambar 3: Bentuk produk padat kering menjadi bubuk

Produk yang telah berbentuk bubuk selanjutnya dikemas menggunakan kemasan produk bubuk berbentuk persegi empat ukuran 10x10 $\mathrm{Cm}$ berbahan Alumunium Foil yang tentunya lebih tahan dan aman lengkap dengan desain label kemasan yang menarik. Perbandingan kemasan dan label produk sebelum dan setelah pendampingan dilakukan sebagaimana ditunjukkan pada gambar berikut.

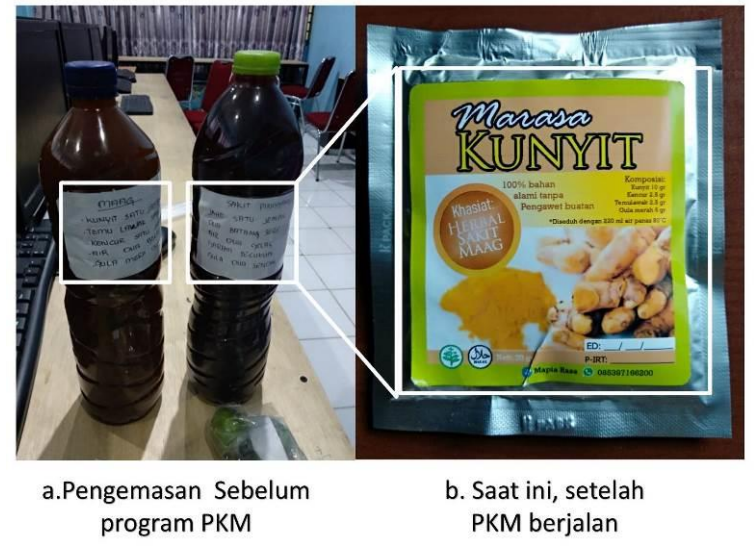

Gambar 4: Perbandingan label dan merek produk sebelum dan setelah kegiatan pendampingan

Sebagaimana ditunjukkan pada Gambar 4 perubahan kemasan produk sangat drastis dilakukan. Perubahan dari bentuk produk cair yang ditransformasi menjadi bubuk sehingga dapat dikemas dengan baik dan lebih terjaga dari sisi kualitas dan keamanan produk. Perubahan label kemasan dilakukan dengan menggunakan aplikasi desain grafis yang menarik dan sesuai tujuan pelabelan dalam kemasan.

Perubahan yang awalnya hanya berupa label tulisan tangan, melalui pendampingan dibuatkan label kemasan yang mebih menarik. Perubahan signifikan terlihat pada kemasan, diantaranya (1) pemberian merek "Marasa Kunyit", (2) informasi Komposisi bahan yang digunakan untuk 
membuat produk, (3) Kolom isian informasi masa produksi dan kadaluarsa, (4) berat bersih, (5) Informasi Kelompok produksi dan (6) Kontak Informasi produk melalui media sosial.

\section{SIMPULAN DAN SARAN}

Kegiatan pendampingan kegiatan melalui pemberdayaan Kelompok Wanita Tani (KWT) Melati terbukti dapat memberikan kontribusi terhadap kualitas produk yang dihasilkan. Hasil Observasi dan evaluasi yang dilakukan menunjukkan bahwa setelah kegiatan PKM dilakukan mitra dapat lebih memahami pentingnya kemasan dan pelabelan produk yang standar, dalam rangka memperluas pasar dan memperkuat daya beli konsumen sasaran. Selain itu kegiatan pendampingan yang dilakukan memberikan pembinaan terkait mekanisme bisnis dan strategi dalam pemasaran produk. Pembuatan kemasan dan label produk dengan pendekatan desain grafis sesuai standar kemasan yang tentunya akan berpengaruh terhadap minat masyarakat konsumen jamu kunyit.

Langkah kerja selanjutnya yang diperlukan dalam pengembangan kuallitas produk adalah kegiatan pendampingan perijinan dan diversifikasi produk. Selain itu kegiatan promosi produk juga perlu dikembangkan ke arah promosi berbasis digital.

\section{DAFTAR RUJUKAN}

Basri, B., \& Qashlim, A. (2018). Pemberdayaan UMKM Desa Kunyi Melalui Potensi Umbi Gadung dengan Pendekatan Promosi berbasis Teknologi. CARADDE: Jurnal Pengabdian Kepada Masyarakat, 1(1), 44-49.

Bora, M. A., \& Bayu, A. (2018). Pengembangan Kemasan Produk Khansa Pizza Untuk Meningkatkan Penjualan Dengan Menggunakan Metode Quality Function Deployment (QFD).

BPS. (2016). Badan Pusat Statistik Kabupaten Polewali Mandar. Retrieved July 13, 2018, from https://polewalimandarkab.bps.go.id/p ublication/2017/12/20/0f0fb86bac110c ab15c2cfcf/sensus-ekonomi-2016analisis-hasil-listing-potensi-ekonomikabupaten-polewali-mandar-.html

Hidayah, R. (2016). Pengaruh Kemasan terhadap Minat Beli Konsumen (Studi pada Produk Sabun Cair LUX di Purworejo. Manajemen-Fakultas Ekonomi.

Mandloi, L. S., Patel, D., Verma, R., Patidar, I., Ramsing, S., Bautze, D., ... Bhullar, G. S. (2014). Participatory Technology Development (PTD) Trials in India.

Pramudita, S. (2013). PENGARUH SIKAP KONSUMEN PADA KOMPONEN IKON VISUAL MEREK TERHADAP MINAT BELI (Studi Eksplanatif Kuantitatif Mengenai Pengaruh Sikap Konsumen pada Komponen Ikon Visual Merek J. CO Donuts \& Coffee terhadap Minat Beli Produk pada Pengunjung Gerai J. CO Donuts. UAJY.

Pribadi, E. R. (2015). Pasokan dan permintaan tanaman obat Indonesia serta arah penelitian dan pengembangannya. Perspektif, 8(1), 52 64.

Sari, T. A. (2019). Perencanaan Bisnis Katering Bayi Dan Anak Maestro di Kota Semarang. PRAXIS, 1(2), 151-163.

Triyono, A. (2014). Pemberdayaan Masyarakat Melalui Community Development Program Posdaya (Pos Pemberdayaan Keluarga) Pt. Holcim Indonesia Tbk Pabrik Cilacap.

Wibowo, E. A. (2016). Pemanfaatan Teknologi E-Commerce Dalam Proses Bisnis. EQUILIBIRIA, 1(1).

Zakaria, Z. (2018). MODIFIKASI KONSEP PARTICIPATORY RURAL APRAISAL UNTUK PEMBEKALAN KULIAH KERJA NYATA MAHASISWA DI JAWA BARAT, INDONESIA. Dharmakarya, 7(1). 